\title{
Enantioselective Organocatalytic Hantzsch Synthesis of Polyhydroquinolines
}

\author{
Christopher G. Evans and Jason E. Gestwicki ${ }^{*}$ \\ University of Michigan, Department of Pathology and the Life Sciences Institute, 210 Washtenaw \\ Ave., Ann Arbor, MI 48109
}

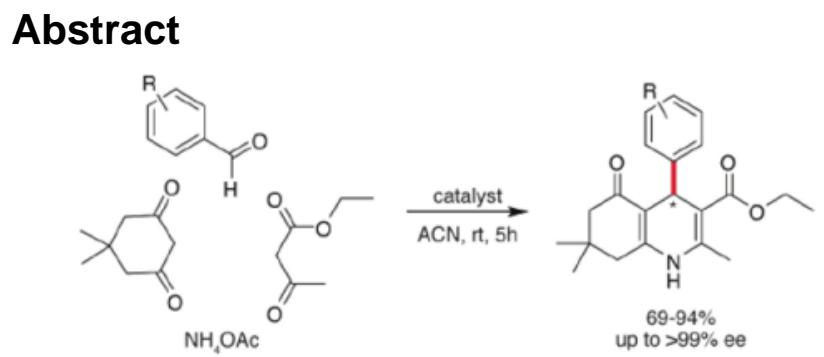

The four component Hantzsch reaction provides access to pharmaceutically important dihydropyridines. To expand the utility of this method, we have developed a route under organocatalytic conditions with good yields and excellent ee's. Through catalyst screening, we found that a BINOL-phosphoric acid allowed enantioselective synthesis of six-membered heterocycles with a variety of substitution patterns.

Multicomponent reactions, such as the Biginelli ${ }^{1}$, Passerini $^{2}, \mathrm{Ugi}^{3}$, and Hantzsch, provide a wide variety of important heterocycles ${ }^{4}$. For example, the Hantzsch reaction provides dihydropyridines with activity against calcium channels, multi-drug resistence (MDR) proteins, 5-hydroxytryptamine (5-HT) receptor and anti-inflammatory targets ${ }^{5}$. Beyond their pharmaceutical applications, Hantzsch-derived dihydropyridines are also useful as synthetic tools for reducing imines to amines ${ }^{6}$.

While enantioselective examples of the Biginelli ${ }^{7}$, Mannich ${ }^{8}$, and Passerini ${ }^{9}$ reactions are well known, parallel methodologies have not been developed for the four-component Hantzsch reaction. Historically, the harsh conditions required for this reaction, such as refluxing ethanol, have made development of an asymmetric route challenging. For example, attempts to use glycosylated enamines to develop diastereoselective products yielded only modest selectivity (Scheme 1$)^{10}$. With more recent advances in Lewis acid-catalyzed reactions, one way to achieve enantio-enrichment is to use an enamine attached to a chiral auxillary in the presence of n-butyllithium (Scheme 1) ${ }^{10}$. While the enrichment values for this method are good to excellent ( $\sim 54$ to $96 \%$ ), this approach reduces the reaction to three components and limits the diversity of the corresponding products. In this report we sought to develop a relatively benign and efficient method to produce enantio-enriched, four-component Hantzsch products.

As a model reaction, we selected a known polyhydroquinoline that would afford one stereocenter (Table 1). Consistent with previous reports, one equivalent dimedone ( $0.4 \mathrm{mmol})$,

gestwick@umich.edu.

Supporting Information Available: General experimental methods, HPLC methods, data for determining ee values, optical activity data, and ${ }^{1} \mathrm{H}$ and ${ }^{13} \mathrm{C}$ spectra. This information is available free of charge via the Internet at http://pubs.acs.org. 
ethylacetoacetate, a benzaldehyde and ammonium acetate, in the presence of $\mathrm{Yb}(\mathrm{OTf})_{3}(10$ mol \%), produced product 4a in both ethanol and acetonitrile (entries 2-3, Table 1). Work-up consisted of precipitating with $1 \mathrm{~mL}$ of ice/water, stirring for approximately one hour, filtering the precipitate and recrystallizing the product from a ethanol:water system ( $3: 1 \mathrm{vol})$. Using this procedure, we found good yields ( $68 \%$ in ethanol and $72 \%$ in acetonitrile), but the reaction also resulted in formation of the symmetrical side product, which lacked the dimedone. In an attempt to minimize this competing pathway, the equivalents of dimedone were systematically increased (entries 4-6, Table 1). At 1.5 equivalents, the yield increased to $90 \%$ with concomittant reduction in the side product. Next, we attempted to reduce the catalyst concentration by screening at 5.0, 1.0 and $0.1 \mathrm{~mol} \%$. In each case, decreasing the catalyst levels reduced the yield (84, 65 and 52\% respectively; entries 8-10 Table 1). Based on these observations, we selected $10 \mathrm{~mol} \%$ catalyst and 1.5 equivalents of dimedone for further studies.

Using these conditions, our plan was to screen organocatalysts for those that would afford a high degree of enantioselectivity. A limited number of chiral Lewis acids ${ }^{10}$ as well as proline and its derivatives ${ }^{11}$ have been explored in this context, but these have produced modest stereoselectivity. Guided by those findings, we focused on a proline-derived catalyst (I) and an expanded series of Lewis acid catalysts (II-VII). To estimate the enantio-enrichment of the products, we used polarimetry in combination with chiral HPLC. Using this approach, we found that catalyst I provided good yields ( $86 \%$ ) but no appreciable enrichment. Next, a series of phosphine based ligands (BINAP-II and III, DPPF-IV, and DPE-V) was explored. These catalysts were used at $10 \mathrm{~mol} \%$ with $11 \mathrm{~mol} \%$ of a co-catalyst, $\mathrm{Pd}(\mathrm{OAc})_{2}$, which provided yields between $75-84 \%$ but no enantio-enrichment. Finally, we synthesized ${ }^{12}$ and explored chiral BINOL-phosphoric acid derivatives (VI and VII). Both catalysts provided good yields (84-85\%) and $98 \%$ ee (Table 2), suggesting that enantio-enriched dihydropyridines could be assembled by this route.

One of the expected advantages of an enantioselective four-component Hantzsch reaction is in the synthesis of substituted dihydropyridines. Of particular interest are the 4-aryl functionalized products, which are employed in many synthetic and medicinal applications 5 , 6 . Towards this goal, we selected a series of substituted aromatic aldehydes and generated the corresponding polyhydroquinolines ( $4 \mathrm{a}-1$ and $4 \mathrm{n}-\mathrm{o}$; Table 3 ). These experiments revealed that most reactions involving aromatic aldehydes proceed to the expected product in good yield (80-94\%), although the aldehydes with unprotected polar groups (e.g. 4k and 4l) generally had moderately lower yields (69-72\%). Importantly, excellent enantio-enrichment values (87 to $>99 \%$ ) were observed for all the products arising from aromatic aldehydes. Conversely, reactions involving alkyl aldehydes proceeded in good yield (66-94\%), but with no enantioenrichment. In these cases, the size of the appended functionality appeared to dictate the outcome; bulky substitutions, such as those installed by cinnamaldehyde $(4 \mathrm{~m} ; 94 \%)$, resulted in significantly better \% ee than smaller groups, such as 2 -methylbutyraldehyde (4p) or acetaldehyde (4q).

In summary, we have developed an enantioselective route for the Hantzsch reaction using a chiral phosphoric acid organocatalyst. This enantioselective route proceeded under relatively mild conditions and resulted in good yields for a range of aromatic aldehydes. This method may find use in the synthesis of medically important dihydropyridines and reagents for enantioselective hydrogenation reactions.

\section{Supplementary Material}

Refer to Web version on PubMed Central for supplementary material. 


\section{Acknowledgments}

We thank D. Ingle, H. Showalter, S. Kawamoto, S. Wang, A. Herath, J. Phillips and J. Montgomery (University of Michigan) for discussions, reagents and access to equipment. This work was supported by a Cellular Biotechnology Training Program predoctoral fellowship (GM008353-18) to C.G.E. and grants from the McKnight Foundation, Alzheimer's Association (IIRG-07-60067) and NIH (NS059690) to J.E.G.

\section{References}

1. (a) Chebanov VA, Muravyova EA, Desenko SM, Musatov VI, Knyazeva IV, Shishkina SV, Shishkin OV, Kappe CO. J Comb Chem 2006;8:427-434. [PubMed: 16677013] (b) Dallinger D, Kappe CO. Nat Protoc 2007;2:1713-1721. [PubMed: 17641636] (c) Dondoni A, Massi A, Sabbatini S, Bertolasi V. J Org Chem 2002;67:6979-6994. [PubMed: 12353991] (d) Kappe CO. Eur J Med Chem 2000;35:1043-1052. [PubMed: 11248403] (e) Ma Y, Qian C, Wang L, Yang M. J Org Chem 2000;65:3864-3868. [PubMed: 10864778] (f) Nilsson BL, Overman LE. J Org Chem 2006;71:77067714. [PubMed: 16995677] (g) Pisani L, Prokopcova H, Kremsner JM, Kappe CO. J Comb Chem 2007;9:415-421. [PubMed: 17341121] (h) Vugts DJ, Jansen H, Schmitz RF, de Kanter FJ, Orru RV. Chem Commun (Camb) 2003:2594-2595. [PubMed: 14594297] (i) Vugts DJ, Koningstein MM, Schmitz RF, de Kanter FJ, Groen MB, Orru RV. Chem Eur J 2006;12:7178-7189.

2. Xu LW, Xia CG, Li L. J Org Chem 2004;69:8482-8484. [PubMed: 15549824]

3. Fewell SW, Smith CM, Lyon MA, Dumitrescu TP, Wipf P, Day BW, Brodsky JL. J Biol Chem 2004;279:51131-51140. [PubMed: 15448148]

4. (a) Chebanov VA, Saraev VE, Desenko SM, Chernenko VN, Shishkina SV, Shishkin OV, Kobzar KM, Kappe CO. Org Lett 2007;9:1691-1694. [PubMed: 17385876] (b) De Silva RA, Santra S, Andreana PR. Org Lett 2008;10:4541-454. [PubMed: 18811177] (c) Dondoni A, Massi A, Sabbatini S, Bertolasi V. J Org Chem 2002;67:6979-6994. [PubMed: 12353991] (d) Glasnov TN, Stadlbauer W, Kappe CO. J Org Chem 2005;70:3864-3870. [PubMed: 15876072] (e) Groenendaal B, Ruijter E, Orru RV. Chem Commun (Camb) 2008:5474-5489. [PubMed: 18997927] (f) Ng PY, Masse CE, Shaw JT. Org Lett 2006;8:3999-4002. [PubMed: 16928058] (g) Ramon DJ, Yus M. Angew Chem Int Ed Engl 2005;44:1602-1634. [PubMed: 15719349] (h) Rivera DG, Vercillo OE, Wessjohann LA. Org Biomol Chem 2008;6:1787-1795. [PubMed: 18452014] (i) Santra S, Andreana PR. Org Lett 2007;9:5035-5038. [PubMed: 17956113] (j) Wei J, Shaw JT. Org Lett 2007;9:4077-4080. [PubMed: 17760458] (k) Wipf P, Stephenson CR. Org Lett 2005;7:1137-1140. [PubMed: 15760158] (l) Wisén S, Androsavich J, Evans CG, Chang L, Gestwicki JE. Bioorgan Med Chem Lett 2008;18:60-65.

5. (a) Cherkupally SR, Mekala R. Chem Pharm Bull (Tokyo) 2008;56:1002-1004. [PubMed: 18591819] (b) Das B, Ravikanth B, Ramu R, Vittal Rao B. Chem Pharm Bull (Tokyo) 2006;54:1044-1045. [PubMed: 16819229] (c) Dondoni A, Massi A, Aldhoun M. J Org Chem 2007;72:7677-7687. [PubMed: 17803318] (d) Miri R, Mehdipour A. Bioorg Med Chem 2008;16:8329-8334. [PubMed: 18701304] (e) Tu S, Zhu X, Zhang J, Xu J, Zhang Y, Wang Q, Jia R, Jiang B, Zhang J, Yao C. Bioorg Med Chem Lett 2006;16:2925-2928. [PubMed: 16563758] (f) Tu SJ, Jiang B, Jia RH, Zhang JY, Zhang Y, Yao CS, Shi F. Org Biomol Chem 2006;4:3664-3668. [PubMed: 16990942] (g) Tu SJ, Jiang B, Zhang JY, Jia RH, Zhang Y, Yao CS. Org Biomol Chem 2006;4:3980-3985. [PubMed: 17047879]

6. (a) Kang Q, Zhao ZA, You SL. Org Lett 2008;10:2031-2034. [PubMed: 18422288] (b) Ouellet SG, Walji AM, MacMillan DW. Acc Chem Res 2007;40:1327-1339. [PubMed: 18085748] (c) Storer RI, Carrera DE, Ni Y, MacMillan DW. J Am Chem Soc 2006;128:84-86. [PubMed: 16390133] (d) Tuttle JB, Ouellet SG, MacMillan DW. J Am Chem Soc 2006;128:12662-12663. [PubMed: 17002356]

7. (a) Gong LZ, Chen XH, Xu XY. Chem Eur J 2007;13:8920-8926. (b) Huang Y, Yang F, Zhu C. J Am Chem Soc 2005;127:16386-16387. [PubMed: 16305212]

8. (a) Lou S, Taoka BM, Ting A, Schaus SE. J Am Chem Soc 2005;127:11256-11257. [PubMed: 16089450] (b) Lou S, Dai P, Schaus SE. J Org Chem 2007;72:9998-10008. [PubMed: 18047372]

9. Andreana PR, Liu CC, Schreiber SL. Org Lett 2004;6:4231-4233. [PubMed: 15524450]

10. (a) Dondoni A, Massi A. Mol Divers 2003;6:261-70. [PubMed: 15068090] (b) Enders D, Muller S, Demir AS. Tetrahedron Lett 1988;29:6437-6440. (c) Franke PT, Johansen RL, Bertelsen S, Jorgensen KA. Chem Asian J 2008;3:216-224. [PubMed: 18080260]

11. (a) Kumar A, Maurya RA. Tetrahedron 2007;63:1946-1952. (b) Legeay JC, Goujon JY, Vanden Eynde JJ, Toupet L, Bazureau JP. J Comb Chem 2006;8:829-833. [PubMed: 17096571] (c) Vohra 
RK, Bruneau C, Renaud JL. Adv Synth Catal 2006;348:2571-2574. (d) Wang LM, Sheng J, Zhang L, Han JW, Fan ZY, Tian H, Qian CT. Tetrahedron 2005;61:1539-1543.

12. Kumar A, Maurya RA. Tetrahedron 2007;63:1946-1952.

13. (a) Chen XH, Xu XY, Liu H, Cun LF, Gong LZ. J Am Chem Soc 2006;128:14802-14803. [PubMed: 17105279] (b) McDougal NT, Schaus SE. J Am Chem Soc 2003;125:12094-12095. [PubMed: 14518986] (c) Schrock RRJJY, Dolman SJ, Miller SA, Bonitatebus PJ, Hoyveda AH. Organometallics 2002;21:409-417. 


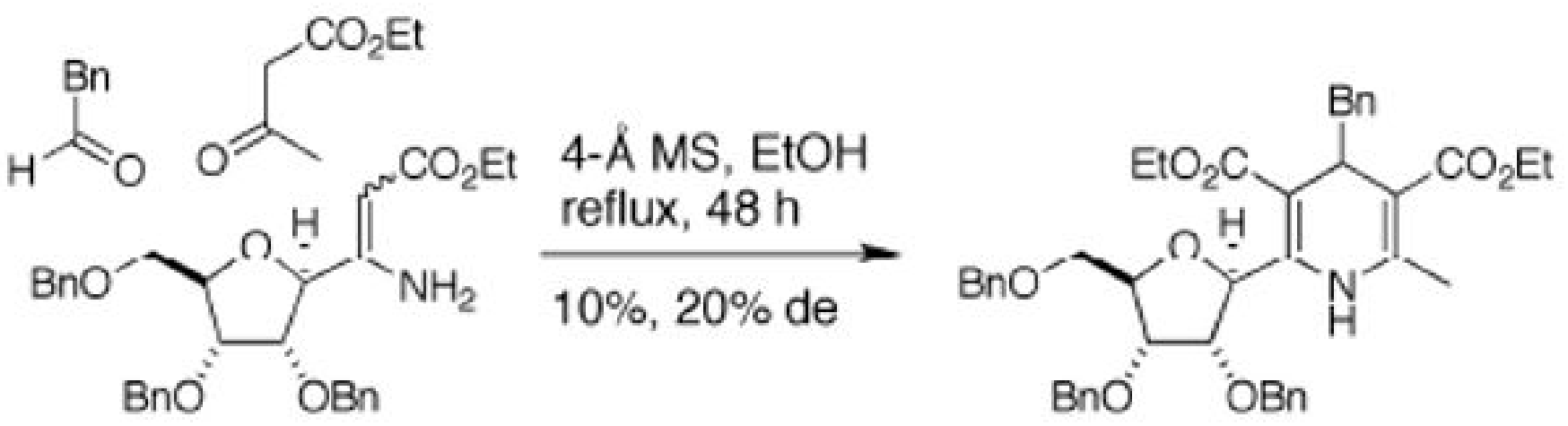<smiles>[R20]OC(=O)C1=C(C)NC(C)=C(C([R20])=O)C1c1cccc([R9])c1</smiles>

Scheme 1. Current Methodology

(A) Asymmetric three-component Hantzsch reaction using C-glysylated reagents

(B) Enantioselective Hantzsch variant employing a chiral auxiliary 


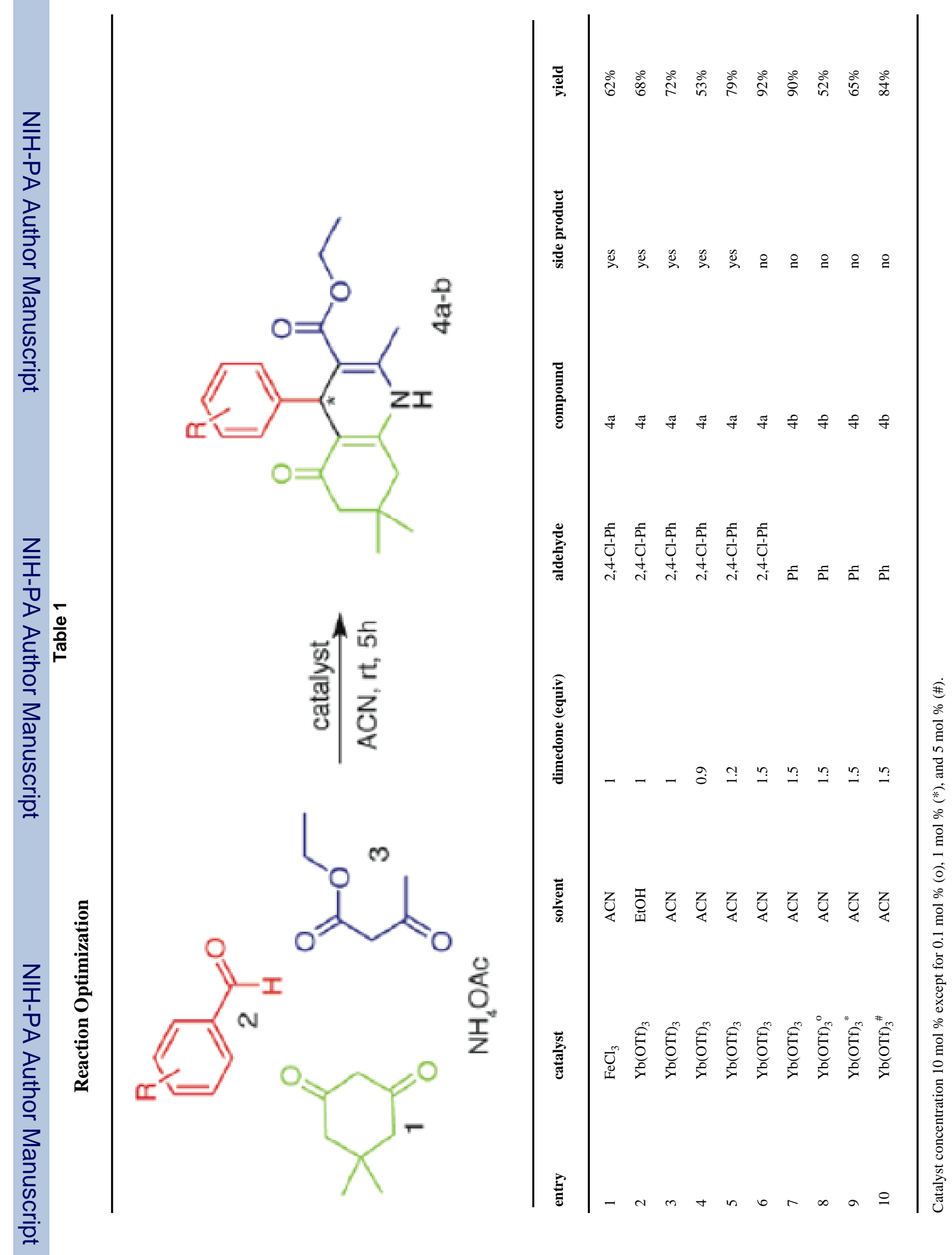

Org Lett. Author manuscript; available in PMC 2010 July 16. 

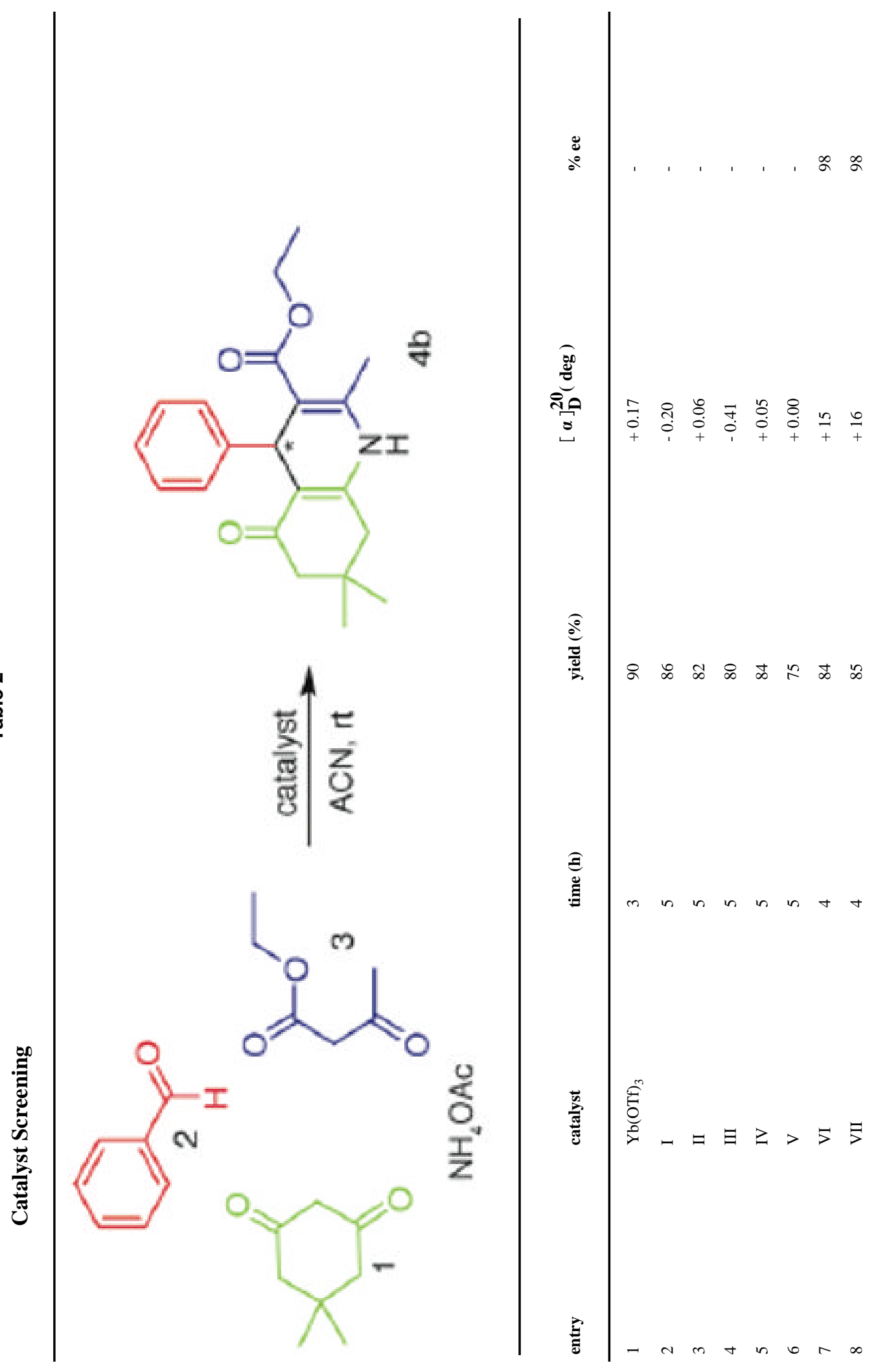

Org Lett. Author manuscript; available in PMC 2010 July 16. 


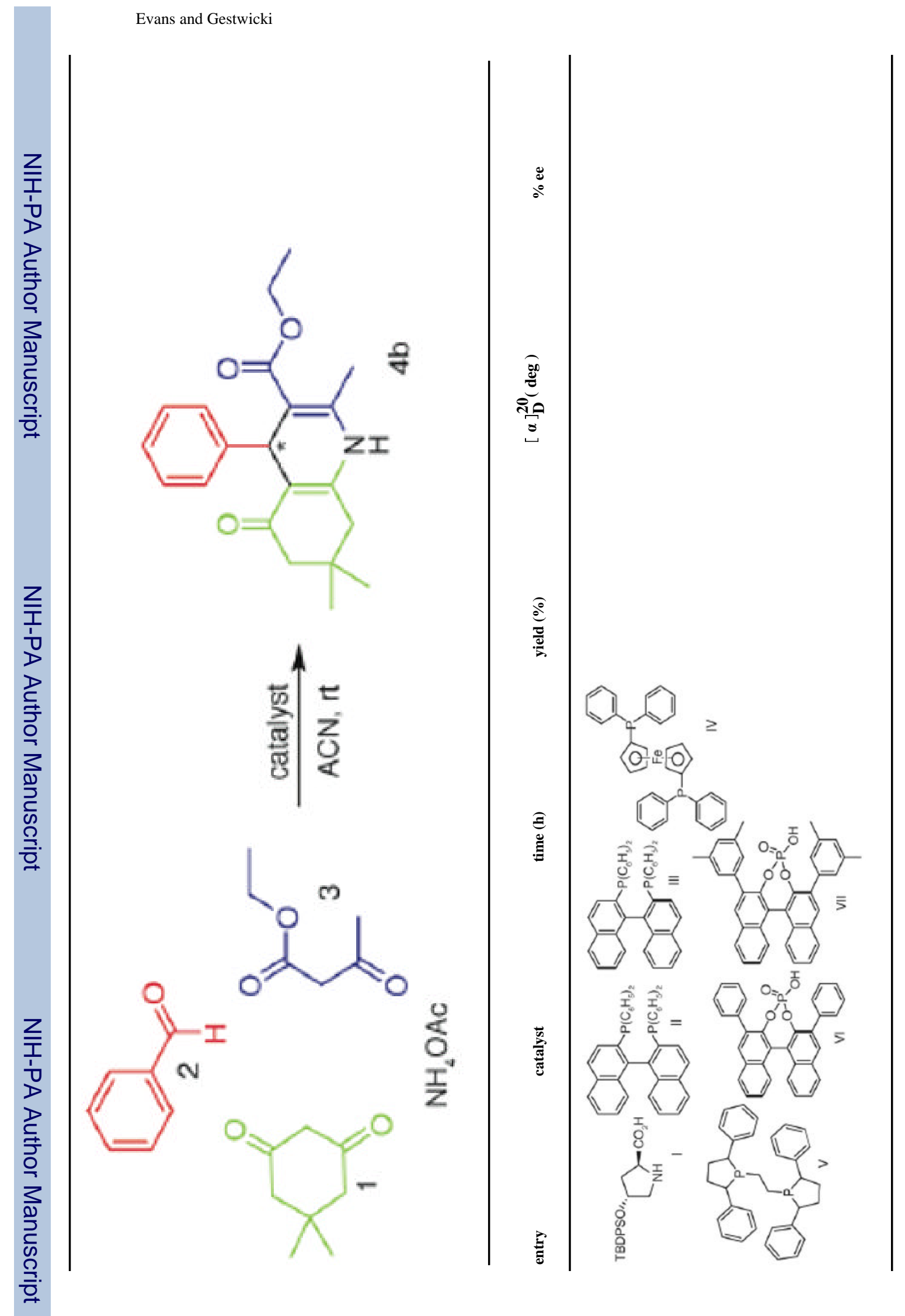

Org Lett. Author manuscript; available in PMC 2010 July 16. 


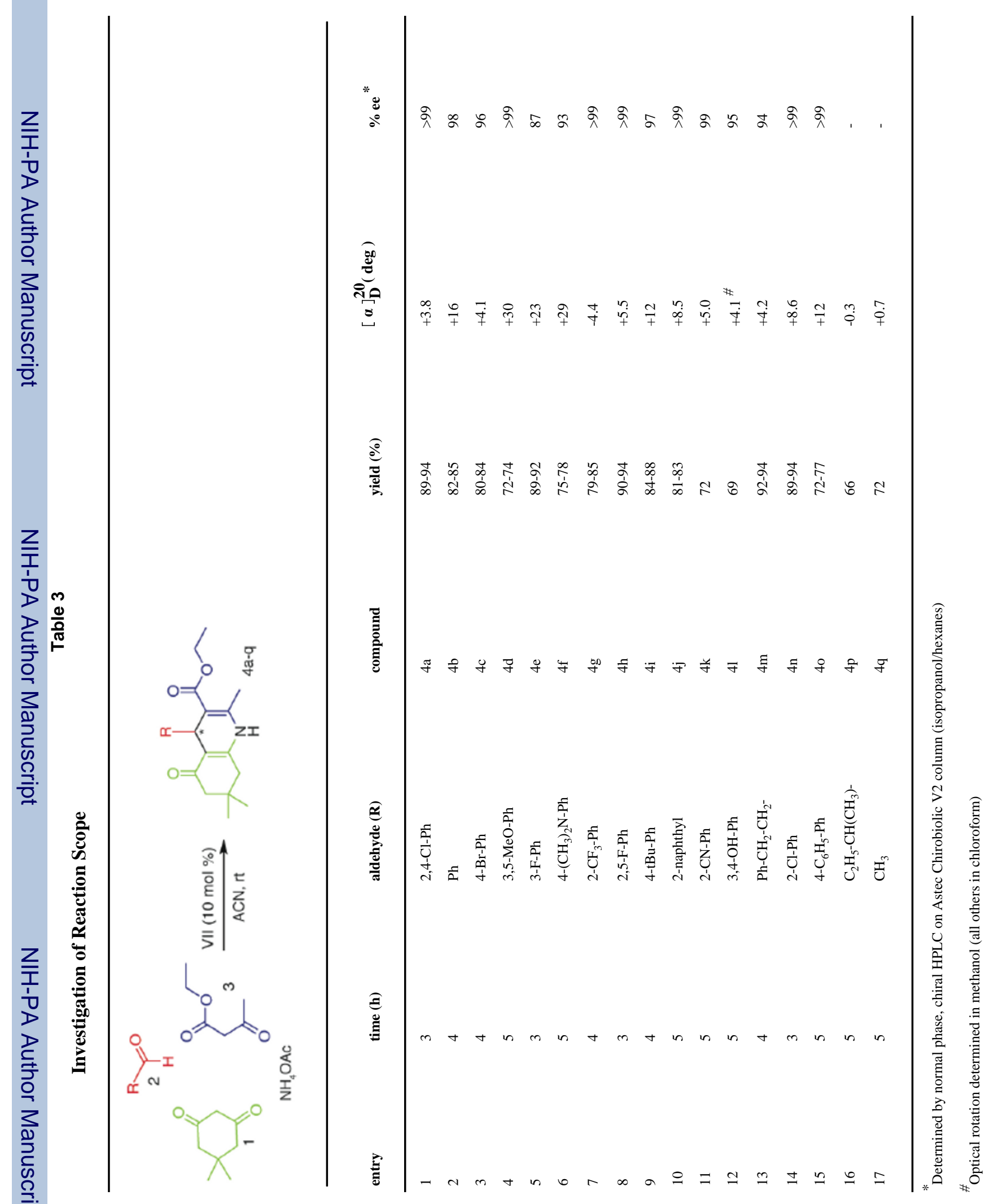

Org Lett. Author manuscript; available in PMC 2010 July 16. 